\title{
OCCUPANT PERCEPTION OF THERMAL COMFORT IN SLEEP ENVIRONMENTS IN QATAR
}

\author{
Madhavi Indraganti ${ }^{*},{ }^{1}$, Farsana Kutty ${ }^{1}$, Reem Ali $^{1}$, Lulwa Al Noaimi ${ }^{1}$, \\ Saaeda Al-Bader ${ }^{1}$ and Maryam Adel Al Mulla ${ }^{1}$ \\ Department of Architecture and Urban Planning, College of Engineering, Qatar University, Doha, Qatar
}

\begin{abstract}
A thermal comfort field survey in sleep environments was conducted in Qatar during winter and spring seasons. A total of 833 sets of objective and subjective thermal and sleep quality responses before going to bed and after getting up were collected. The subjects felt cooler sensations most of the time, preferred warmer sensations and the sleep environments are considered comfortable overall. Griffiths comfort temperature (Tc) was $24.3{ }^{\circ} \mathrm{C}$ and $20.2{ }^{\circ} \mathrm{C}$ in free-running (FR) and air-conditioned (AC) modes respectively. Subjects used airconditioner (AC)s adaptively in heating mode in winter. In $82.7 \%$ of cases in (AC) mode, the comfort temperature was below the lower limit of the international standard. Subjects enjoyed quality sleep in Qatar. Overall, selfdeclared sleep quality improved with thermal acceptability. Depth of sleep was higher in AC mode (mean $=3.86$ ). On the other hand, the mean global Pittsburgh Sleep Quality Index (PSQI) score was high in general (mean = 10.7), indicating good quality sleep, and significantly so in free-running mode (mean $=11$ ) than in AC mode (mean $=10.4$ ). It increased, as subjects liked their AC systems. This study suggests that overcooling in spring can be avoided by increasing air movement without compromising sleep quality.
\end{abstract}

Keywords: Bedroom; Comfort Temperature; Occupant Behavior; Quality of Sleep; Thermal Comfort

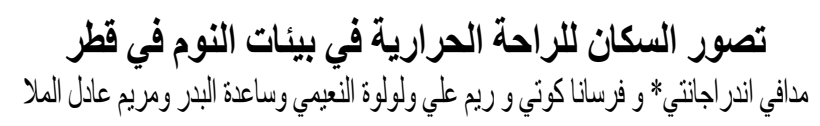

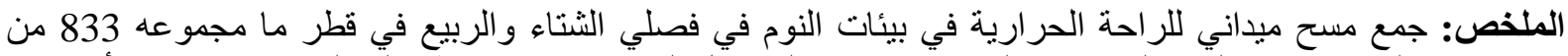

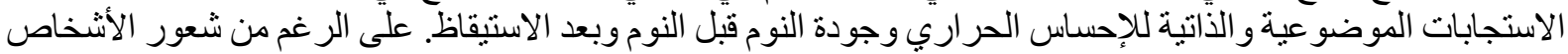

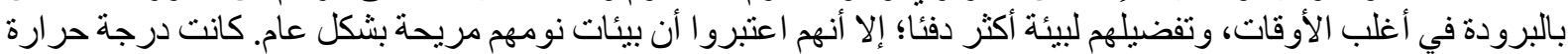

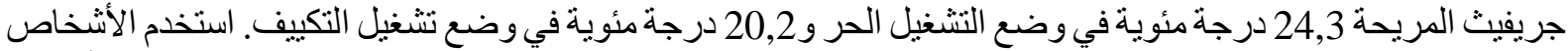

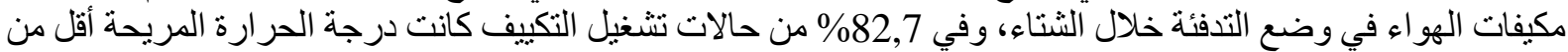

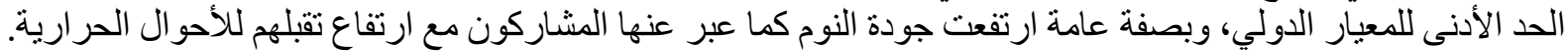

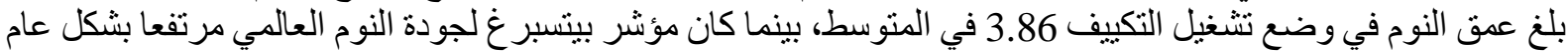

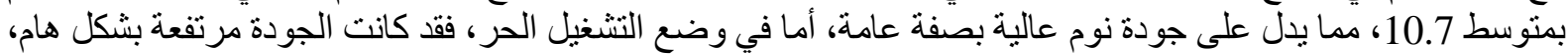

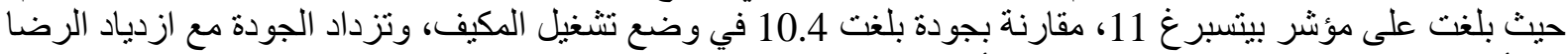

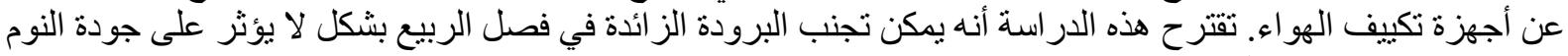
عن طريق زيادة حركة الهو أهرو

الكلمات المفتاحية: الراحة الحر ارية؛ التهوية؛ جودة النوم؛ التكييف.

*Corresponding author’s e-mail: madhavi@qu.edu.qa 


\section{INTRODUCTION}

Sleep is a basic human need and quality sleep is vital for human health and wellbeing. It is known for a long that sleep quality and bedroom temperature are negatively correlated (Humphreys, 1970). Recent studies have found that room freshness (lower $\mathrm{CO}_{2}$ levels) significantly enhanced the occupant's sleep quality, performance in a test of logical thinking, and reduced the symptoms of the next day reported sleepiness (Strøm-Tejsen, et al., 2016). That elevated air movement enhances sleep quality and fans could be used to great advantage in heatwave situations are now well established through biophysical modelling and field experiments (Morris, et al., 2021; Lan, et al., 2019).

Literature also pointed to subjects sleeping well in Japanese homes with the help of adaptive measures such as using cooling devices and fans (Imagawa \& Rijal, 2015). In this context, it is important to note that buildings in Qatar are maintained at near-zero indoor airspeeds (Indraganti \& Boussaa, 2018). Cheap energy prices coupled with long hot and humid seasons increase the air-conditioner usage and overcooling in buildings is rampant in the Gulf Cooperation Countries (GCC) (Elnaklah, et al., 2021; Indraganti \& Boussaa, 2018).

Further, in Qatar, the final electricity consumption in the residential sector is very high (45\%) and has increased by $33 \%$ between $2015-18$. While the country ranked highest in per capita $\mathrm{CO}_{2}$ emissions in the world (IEA, 2018). Moreover, building energy for space cooling and heating contributes substantially to greenhouse gas emissions. Gulf nations like Qatar have already witnessed average (outdoor) temperature increases of over $2^{\circ} \mathrm{C}$ (Al-Saffar \& Beeuren, 2020).

As there is no custom-developed adaptive thermal comfort standard for the GCC, engineers usually use the predicted mean vote (PMV) approach for indoor environmental design, following international standards (Global Sustainability Assessment System (GSAS, 2015; ASHRAE, 2020; ISO, 2005). Researchers claimed that this approach was inaccurate in predicting actual thermal comfort and suggested a transition in the air-conditioning practice towards the adaptive framework (Humphreys \& Nicol, 2002; Cheung, et al., 2019; Parkinson, et al., 2020). Thermal comfort in residential spaces and especially sleep environments are under-reported in the Middle East. Therefore, a field study was conducted to investigate the thermal comfort, quality of sleep and occupant adaptive behaviour in sleep environments of six residences in Qatar in the winter and spring seasons.

\section{METHODOLOGY}

\subsection{Survey Location and Buildings Surveyed}

Qatar is a small nation in the Arabian Peninsula with a hot desert climate (Bwh in Köppen climate classification). Its capital is Doha (N25 17', E51 ${ }^{\circ} 32^{\prime}$,
$10 \mathrm{~m}$ above the mean sea level). It has five months of harsh summer (May - September) and mild winter (December - February) with very low precipitation. Autumn (October, November) and spring (March, April) are short mild seasons of two months each. This is an ongoing longitudinal survey in six randomly selected residences (B1-B6) involving nine healthy participants in Doha metropolitan area. This paper includes the data from December 28, 2020 - March 29, 2021, consisting of 833 sets of subjective thermal responses and simultaneous objective environmental measurements. The SARS-COV-19 pandemic after March 2020 affected the data collection. Table 1 shows the details of the buildings surveyed (Figure 1). The buildings are multi-storied low-rise apartment blocks and independent villas. They have a concrete structural frame and concrete block masonry infill walls with sliding and sash windows, a typical style used locally. Only B1 had portable fans. Buildings B1-B5 have cloth curtains while B6 had roller blinds. No data was collected about the heating set points in the survey.

\subsection{Data Collection}

Set to a 10-minute interval, calibrated sensors of the data loggers were fixed to a hanger or a board at $1.1 \mathrm{~m}$ height from the floor in all the bedrooms. They recorded indoor air temperature $\left(\mathrm{T}_{\mathrm{a}}\right)$, globe temperature $\left(\mathrm{T}_{\mathrm{g}}\right)$, relative humidity $(\mathrm{RH})$ and air velocity $\left(\mathrm{V}_{\mathrm{a}}\right)$ in all bedrooms. Excepting in B2, B4, $\mathrm{CO}_{2}$ concentration was also measured in all the other houses. The outdoor daily mean temperature $\left(T_{0}\right)$ was obtained from the meteorological website (Anon., 2021). The mean radiant temperature $\left(T_{m r t}\right)$ is calculated following the procedure in the American Society of Heating, Refrigerating and AirConditioning Engineers (ASHRAE) Handbook (ASHRAE, 2005) and operative temperature $\left(T_{\mathrm{op}}\right)$ was taken as the average value of $\mathrm{T}_{\mathrm{mrt}}$ and $\mathrm{T}_{\mathrm{a}}$ (ASHRAE, 2020). The instrument details and the set-up used in the surveys are shown in Figure 2 and Table 2.

\subsection{Thermal Questionnaire and the Respondents}

Table 3 lists all the scales used in this survey. Nine respondents participated in the survey of which one was a male participant in B4 (Age: 60 years, Sample size (n): 141). It was learned that men in Arab families usually spend winters in tent structures "kashta” (كثته) in the desert away from homes, and, therefore, our survey recruited fewer men. Consequently, we collected $83.1 \%$ data from females (mean age: 30.2 (standard deviation (SD) (11.1) years). The bedrooms in B4 and B6 had two subjects each, while the rest had one each. Male and female samples are treated independently to avoid sampling bias.

Aged 21-60 years (mean: $35.3 \pm 15.1$ years), the respondents are all healthy residents of Qatar living in the surveyed areas for longer than one year and are assumed to be acclimatized to the local climate. No physiological data of the subjects were collected in this study. 
Madhavi Indraganti, Farsana Kutty, Reem Ali, Lulwa Al Noaimi, Saeeda Al-Bader and Maryam Adel Al-Mulla

Table 1. Details of the buildings surveyed.

\begin{tabular}{|c|c|c|c|c|c|c|c|c|c|c|}
\hline $\begin{array}{c}\text { House } \\
\text { (Sample size) } \\
\text { respondents }\end{array}$ & Location & Typology & $\begin{array}{c}\text { Floor } \\
\text { surveyed }\end{array}$ & $\begin{array}{l}\text { Room } \\
\text { area } \\
\left(\mathrm{m}^{2}\right)\end{array}$ & $\begin{array}{l}\text { Ceiling } \\
\text { height } \\
\text { (m) }\end{array}$ & $\begin{array}{c}\text { AC } \\
\text { System }\end{array}$ & Thermostat & Window & Glazing & $\begin{array}{r}\text { Window } \\
\text { area }\left(\mathrm{m}^{2}\right)\end{array}$ \\
\hline B1 (110) 1 & Najma & $\begin{array}{c}\text { Single } \\
\text { apartment }\end{array}$ & 2 & 14.5 & 3.2 & Window & $\begin{array}{c}\text { Wall- } \\
\text { mounted }\end{array}$ & Sliding & Single & 1.98 \\
\hline B2 (69) 1 & $\begin{array}{l}\text { Madinat } \\
\text { Khalifa } \\
\text { South }\end{array}$ & $\begin{array}{c}\text { Single } \\
\text { apartment }\end{array}$ & 4 & 17.4 & 2.8 & Split & Hand-held & Sliding & Single & 1.44 \\
\hline B3 (79) 1 & $\begin{array}{c}\text { Al- } \\
\text { Mamoura }\end{array}$ & $\begin{array}{l}\text { Independent } \\
\text { villa }\end{array}$ & 1 & 20 & 3 & Split & Hand-held & Sliding & Single & 1.5 \\
\hline B4 (283) 3 & $\begin{array}{l}\text { Bin- } \\
\text { Mahmoud } \\
\text { South }\end{array}$ & $\begin{array}{l}\text { Apartment in } \\
\text { compound }\end{array}$ & 4 & 21 & 3.5 & $\begin{array}{l}\text { Ducted } \\
\text { Central }\end{array}$ & $\begin{array}{l}\text { Wall- } \\
\text { mounted }\end{array}$ & Sash & Double & 3.75 \\
\hline B5 (87) 1 & Al-Nasr & $\begin{array}{l}\text { Independent } \\
\text { villa }\end{array}$ & 1 & 20 & 3 & Split & Hand-held & Sliding & Double & 1.8 \\
\hline B6 (205) 2 & Al-Tarfa & $\begin{array}{c}\text { Apartment in } \\
\text { compound }\end{array}$ & 1 & 80 & 4.5 & $\begin{array}{l}\text { Ducted } \\
\text { Central }\end{array}$ & $\begin{array}{c}\text { Wall- } \\
\text { mounted }\end{array}$ & Sliding & Double & 3 \\
\hline
\end{tabular}

Table 2. Details of the dataloggers and sensors used in the surveys.

\begin{tabular}{|c|c|c|c|c|c|}
\hline & Description/ manufacturer & Trade name & Parameter Measured & Range & Accuracy \\
\hline \multirow[t]{4}{*}{$\begin{array}{l}\mathrm{B} 2, \\
\mathrm{~B} 4\end{array}$} & \multirow{4}{*}{$\begin{array}{c}\text { Thermo-hygro datalogger } \\
\text { with probe thermometer with } \\
\text { black painted table tennis ball } \\
\text { and air velocity sensor; Onset, } \\
\text { Hobo, USA }\end{array}$} & $\begin{array}{c}\text { U12-013 } \\
\text { (Temp/RH/2 Ext) }\end{array}$ & Air temperature & 0 to $50^{\circ} \mathrm{C}$ & $\pm 0.35^{\circ} \mathrm{C}\left(0^{\circ}\right.$ to $\left.50^{\circ} \mathrm{C}\right)$ \\
\hline & & & Humidity & 5 to $90 \% \mathrm{RH}$ & $\pm 2.5 \%$ (10 to $90 \%)$ \\
\hline & & $\begin{array}{l}\text { TMC1-HD probe } \\
\text { with }\end{array}$ & $\begin{array}{c}\text { Globe } \\
\text { temperature }\end{array}$ & 0 to $50^{\circ} \mathrm{C}$ & $\pm 0.35^{\circ} \mathrm{C}\left(0^{\circ}\right.$ to $\left.50^{\circ} \mathrm{C}\right)$ \\
\hline & & $\begin{array}{l}\text { Accusense F900- } \\
\text { O-10-0 hot wire } \\
\text { anemometer }\end{array}$ & Air velocity & $0.15-5 \mathrm{~m} / \mathrm{s}$ & $\pm 0.05 \mathrm{~m} / \mathrm{s}(0$ to $5 \mathrm{~m} / \mathrm{s})$ \\
\hline \multirow{5}{*}{$\begin{array}{l}\text { B1, } \\
\text { B3, } \\
\text { B5, } \\
\text { B6 }\end{array}$} & \multirow[t]{3}{*}{$\begin{array}{l}\text { Onset HOBO Bluetooth } \\
\text { Wireless CO} 2 \text {, Temp \& } \\
\text { Humidity Data Logger }\end{array}$} & MX 1102A & Air temperature & $\begin{array}{c}0^{\circ} \text { to } 50^{\circ} \mathrm{C} \\
\left(32^{\circ} \text { to }\right. \\
\left.122^{\circ} \mathrm{F}\right) \\
\end{array}$ & $\begin{array}{c} \pm 0.21^{\circ} \mathrm{C} \text { from } 0^{\circ} \text { to } \\
50^{\circ} \mathrm{C}\end{array}$ \\
\hline & & & Humidity & $\begin{array}{c}1 \% \text { to } 70 \% \\
\text { RH }\end{array}$ & $\begin{array}{c} \pm 2 \% \text { from } 20 \% \text { to } \\
80 \% \\
\end{array}$ \\
\hline & & & $\begin{array}{c}\mathrm{CO} 2 \\
\text { concentration } \\
\end{array}$ & $\begin{array}{c}0 \text { to } 5,000 \\
\text { ppm }\end{array}$ & $\begin{array}{l} \pm 50 \mathrm{ppm} \pm 5 \% \text { of } \\
\text { reading at } 25^{\circ} \mathrm{C}\end{array}$ \\
\hline & \multirow{2}{*}{$\begin{array}{l}\text { UX120-006M Analogue data } \\
\text { logger with external } \\
\text { temperature probe sensor with } \\
\text { Sibata } 75 \mathrm{~mm} \text { Cu Globe and } \\
\text { DegreeC air velocity sensor. }\end{array}$} & $\begin{array}{l}\text { T-DCI-F300-1A3 } \\
\text { hot wire } \\
\text { anemometer }\end{array}$ & Air velocity & $0.15-5 \mathrm{~m} / \mathrm{s}$ & $\pm 0.05 \mathrm{~m} / \mathrm{s}(0$ to $5 \mathrm{~m} / \mathrm{s})$ \\
\hline & & $\begin{array}{c}\text { TMC1-HD probe } \\
\text { with 080340-275 } \\
\text { Cu globe } \\
\end{array}$ & $\begin{array}{c}\text { Globe } \\
\text { temperature }\end{array}$ & 0 to $50^{\circ} \mathrm{C}$ & $\pm 0.35^{\circ} \mathrm{C}\left(0^{\circ}\right.$ to $\left.50^{\circ} \mathrm{C}\right)$ \\
\hline
\end{tabular}

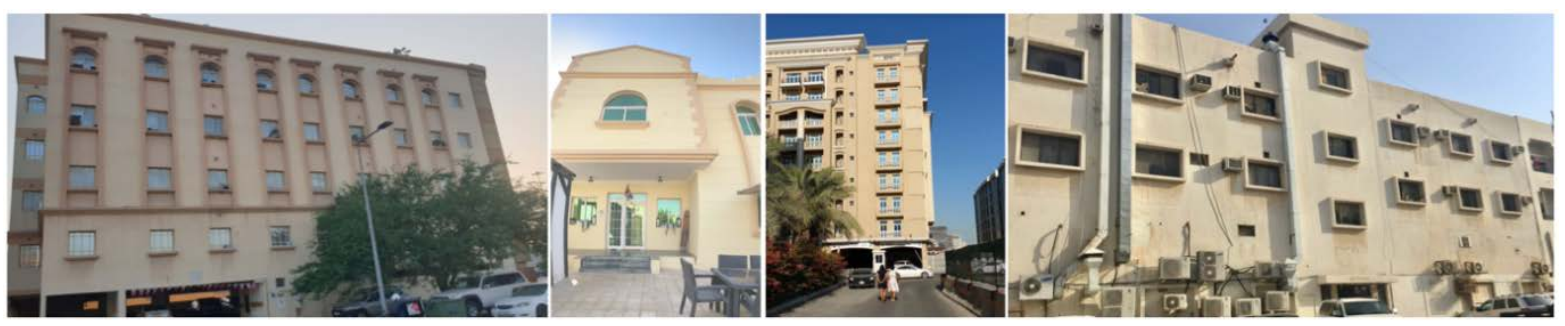

Figure 1. Survey locations and the typical buildings surveyed.
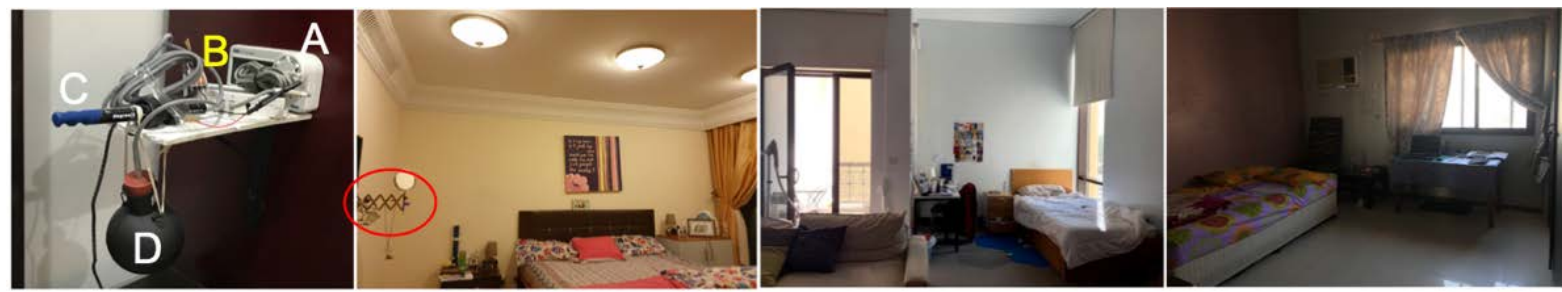

Figure 2. Instrument set-up and the survey environments (A: MX1102A; B: UX120-006M; C: hot-wire anemometer; D: Cu globe with thermal probe). 
Table 3. Scales used in the survey.

\begin{tabular}{|c|c|c|c|c|c|c|c|c|}
\hline $\begin{array}{l}\text { Scale } \\
\text { value }\end{array}$ & $\begin{array}{l}\text { Thermal } \\
\text { sensation } \\
\text { (TSV) }\end{array}$ & $\begin{array}{l}\text { Thermal } \\
\text { preference } \\
\text { (TP) }\end{array}$ & $\begin{array}{l}\text { Overall } \\
\text { comfort (OC) }\end{array}$ & $\begin{array}{l}\text { Depth } \\
\text { of sleep }\end{array}$ & $\begin{array}{l}\text { Sensitivity to } \\
\text { warmth (SW) }\end{array}$ & $\begin{array}{l}\text { Overall } \\
\text { sleep } \\
\text { quality }\end{array}$ & $\begin{array}{l}\text { Preference } \\
\text { on cooling/ } \\
\text { heating }\end{array}$ & $\begin{array}{l}\text { Thermal } \\
\text { acceptability } \\
\text { (TA) }\end{array}$ \\
\hline 6 & & & $\begin{array}{l}\text { Very } \\
\text { comfortable }\end{array}$ & $\begin{array}{l}\text { Very } \\
\text { deep }\end{array}$ & & & & \\
\hline 5 & & & Comfortable & Deep & & & & \\
\hline 4 & & & $\begin{array}{l}\text { Slightly } \\
\text { comfortable }\end{array}$ & $\begin{array}{l}\text { Slightly } \\
\text { deep }\end{array}$ & heat and cold & & & \\
\hline 3 & Hot & & $\begin{array}{l}\text { Slightly } \\
\text { uncomfortable }\end{array}$ & $\begin{array}{l}\text { Slightly } \\
\text { light }\end{array}$ & cold & $\begin{array}{l}\text { Very } \\
\text { good }\end{array}$ & & \\
\hline 2 & Warm & $\begin{array}{l}\text { Much } \\
\text { Cooler }\end{array}$ & Uncomfortable & Light & neither heat nor cold & Good & & \\
\hline 1 & $\begin{array}{l}\text { Slightly } \\
\text { warm }\end{array}$ & $\begin{array}{l}\text { A Bit } \\
\text { Cooler }\end{array}$ & $\begin{array}{l}\text { Very } \\
\text { uncomfortable }\end{array}$ & $\begin{array}{l}\text { Very } \\
\text { light }\end{array}$ & heat & Bad & Like & Unacceptable \\
\hline 0 & Neutral & No Change & & & & Very bad & $\begin{array}{l}\text { Neither like } \\
\text { nor dislike }\end{array}$ & Acceptable \\
\hline-1 & $\begin{array}{l}\text { Slightly } \\
\text { cool }\end{array}$ & $\begin{array}{l}\text { A Bit } \\
\text { Warmer }\end{array}$ & & & & & Dislike & \\
\hline-2 & Cool & $\begin{array}{l}\text { Much } \\
\text { Warmer }\end{array}$ & & & & & & \\
\hline-3 & Cold & & & & & & & \\
\hline
\end{tabular}

Table 4. Descriptive statistics (mean and standard deviation) of outdoor and indoor environmental variables.

\begin{tabular}{llll}
\hline Mode (n) & FR (433) & AC (400) & All (833) \\
\hline Outdoor daily mean temperature $\left({ }^{\circ} \mathbf{C}\right)$ & $20.9(2.4)$ & $21(2.3)$ & $20.9(2.3)$ \\
Outdoor relative humidity $(\%)$ & $59.7(12.1)$ & $60.4(11.6)$ & $60.1(11.8)$ \\
Operative temperature $\left({ }^{\circ} \mathbf{C}\right)$ & $23.9(1.5)$ & $19.8(2.2)$ & $21.9(2.8)$ \\
Air temperature $\left({ }^{\circ} \mathbf{C}\right)$ & $24.1(1.5)$ & $20.1(2.2)$ & $22.2(2.7)$ \\
Relative humidity $(\%)$ & $61.4(5.8)$ & $61.3(6.1)$ & $61.4(5.9)$ \\
Air Velocity $(\mathbf{m} / \mathbf{s})$ & $0.02(0.04)$ & $0.04(0.07)$ & $0.03(0.06)$ \\
\hline
\end{tabular}

The respondents were requested to respond to the online Google survey twice a day: (1) before going to bed after spending 15 minutes in the bedroom and (2) soon after waking up reflecting on the thermal comfort during sleep. The questionnaire was modelled after Imagawa \& Rijal (2015) in English and translated to Arabic. Following Tsang, et al. (2021), the detailed sleep quality questions were prepared to estimate the Pittsburgh Sleep Quality Index (PSQI) (Buysse, et al., 1989).

PSQI is a self-scoring subjective measure of sleep quality in all seven dimensions of sleep such as quality, latency, efficiency, disturbances, medications, and daytime disfunction. A higher PSQI index refers to better sleep quality. To the PSQI, we added the overall sleep quality score and obtained Global PSQI.

The Internal Review Board (IRB) at QU approved the questionnaire for ethical compliance. The ASHRAE 7-point scale was used for evaluating thermal sensation (TSV). The questionnaire had three segments: time and personal identifier/variables followed by branching questions of thermal comfort and the use of controls. A separate one-time background survey collected the building and personal details such as age. The thermal questionnaire included elaborate pictorial checklists for various pieces of garments, three types of bedding, and a list of activities to choose from. It also included a list of environmental controls (AC/fan/heater/ window/curtain/lights) which are coded as 0: not in use, 1: in use and 2: Unavailable. The occupants gave 458 (male: 84 , female: 374 ) and 375 (male: 57, female: 318) datasets before going to bed and after getting up respectively.

\section{RESULTS AND DISCUSSION}

\subsection{Outdoor and Indoor Conditions}

The following sections present the results of the data considered in two groups: FR (free-running - no cooling or heating) and AC (cooling/heating by airconditioning). We used SPSS Ver.27. In FR mode, the mean outdoor temperature was $20.8{ }^{\circ} \mathrm{C}$ and $20.9{ }^{\circ} \mathrm{C}$, before going to bed and after getting up respectively, and similarly, in AC mode it was $21.1{ }^{\circ} \mathrm{C}$ and $20.9{ }^{\circ} \mathrm{C}$ respectively. Likewise, in FR mode, the mean outdoor relative humidity was $60.1 \%$ and $59.4 \%$ before going to bed and after getting up respectively, and similarly, in AC mode it was $59.4 \%$ and $61.8 \%$, respectively. As indoor operative temperature $\left(\mathrm{T}_{\mathrm{op}}\right)$ correlated very strongly $(r=0.999-0.996, p<0.001)$ with other indoor thermal indices $T_{g}, T_{m r t}$ and $T_{a}$. The $t_{o p}$ was selected for 
the analysis to enable easy comparison with literature and standards. The indoor thermal conditions in FR mode were significantly warmer than AC mode (mean difference $=\sim 4.6 \mathrm{~K}, \mathrm{p}<0.05$ ), while the difference in $\mathrm{T}_{\mathrm{op}}$ "before going to bed" and "after getting up" was very small. Comparatively, $\mathrm{RH}$ was less variable among the four conditions examined (Figure 3). This result suggests that people in Doha sleep in humidcooler conditions in AC mode and humid-warmer conditions in FR mode. The descriptive statistics of outdoor and indoor variables are presented in Table 4. Being a winter and spring season study, very low air movement was noted indoors (mean airspeed $=0.03$ $\mathrm{m} / \mathrm{s}$ ). The clothing insulation $\left(\mathrm{I}_{\mathrm{cl}}\right)$ for all subjects before and after the sleep was estimated. The $\mathrm{I}_{\mathrm{cl}}$ values of Western and non-Western ensembles were estimated using the standard checklists and reports (ASHRAE, 2020; ISO, 2005; Indraganti, et al., 2015; Havenith, et al., 2015; Mitsuzawa \& Tanabe, 2001; Al-ajmi, et al., 2008). The bedding and mattress insulations were estimated following Lin \& Deng (2008), assuming the subjects to be using similar mattresses and heavy/light duvets and blankets. The metabolic rates were estimated as per (ISO, 2005).

\subsection{Subjective Thermal Responses}

Overall, the mean thermal sensation was found to be 0.19 (standard deviation: 1.1), indicating that the subjects voted on the cooler side of the 7-point sensation scale. In FR and AC modes it was -0.20 and -0.17 respectively, implying that the subjects were often feeling cooler sensations. In both FR and AC modes, subjects were feeling significantly warmer sensations after getting up (by about $1 / 2$-sensation vote) $(p<0.05)$. Interestingly, the literature indicates that warmer thermal sensations (TSV $>0.8$ ) are counterproductive to sleep quality improvement (Song, et al., 2020). Much as expected, the preference (TP) was for warmer environments with the mean TP vote being -0.14 overall (Figure 4 ).

In FR mode, TP was significantly different before going to bed and after getting up ( $\mathrm{p}<0.05)$, but not in AC mode. The preference for warmer environments was significantly higher in FR mode. This is in part due to the general warmer environment preferences of people noted in the winter season in FR mode, which is not so prominent in AC mode. While the overall comfort (OC) of subjects was the highest in AC mode after getting up, no significant differences before sleep and after sleep were noted in the OC vote.

The results also indicated that subjects were comfortable with their sleep environments most of the time, with the proportion of subjects voting on the comfortable side of the OC scale being $63.2 \%-83.3 \%$ and the proportion comfortable $(-1 \leq \mathrm{TSV} \leq 1)$ also being high (79\% - 93\%) in all the four cases considered as above (Figure 4). This result is comparable to the 80\% satisfaction rate suggested in ASHRAE Std-55 (ASHRAE, 2020).

\subsection{Estimation of Comfort Temperature}

Comfort temperature refers to the temperature needed indoors for people to feel comfortable. Linear regression is one of the methods used to estimate it. In this study, we regressed $T_{\text {op }}$ with TSV and obtained the following relationship for FR mode:

$T S V=0.167 T_{o p}-4.185(r=0.253, p<0.001$,

where $n=433$, standard error $(S E)=0.031)$

The equation in AC mode was not significant at $95 \%$ confidence interval (CI) and the slopes for "before going to bed" and "after getting up" cases were found to be homogenous at $95 \%$ CI. This relationship returned a comfort neutral temperature of $25.1{ }^{\circ} \mathrm{C}$ in FR mode and a comfort band $(-1 \leq \mathrm{TSV} \leq 1)$ of $19.1{ }^{\circ} \mathrm{C}$ $31.5^{\circ} \mathrm{C}$. The mean $\mathrm{T}_{\text {op }}$ when subjects voted neutral in FR mode was $24{ }^{\circ} \mathrm{C}$ (SD: 1.2), which was slightly lower than the regression natural temperature. In AC mode, it was $20.2{ }^{\circ} \mathrm{C}$ (SD: 2.2 ). Often, it is noted in field experiments that both subjective sensation and or the thermal stimuli do not fluctuate much, and, consequently, the regression equation may not be significant, as in the case of AC mode in this study (Humphreys, et al., 2016, p. 287). Therefore, the literature points to the use of the Griffiths method to evaluate the comfort temperature (Griffiths, 1990).
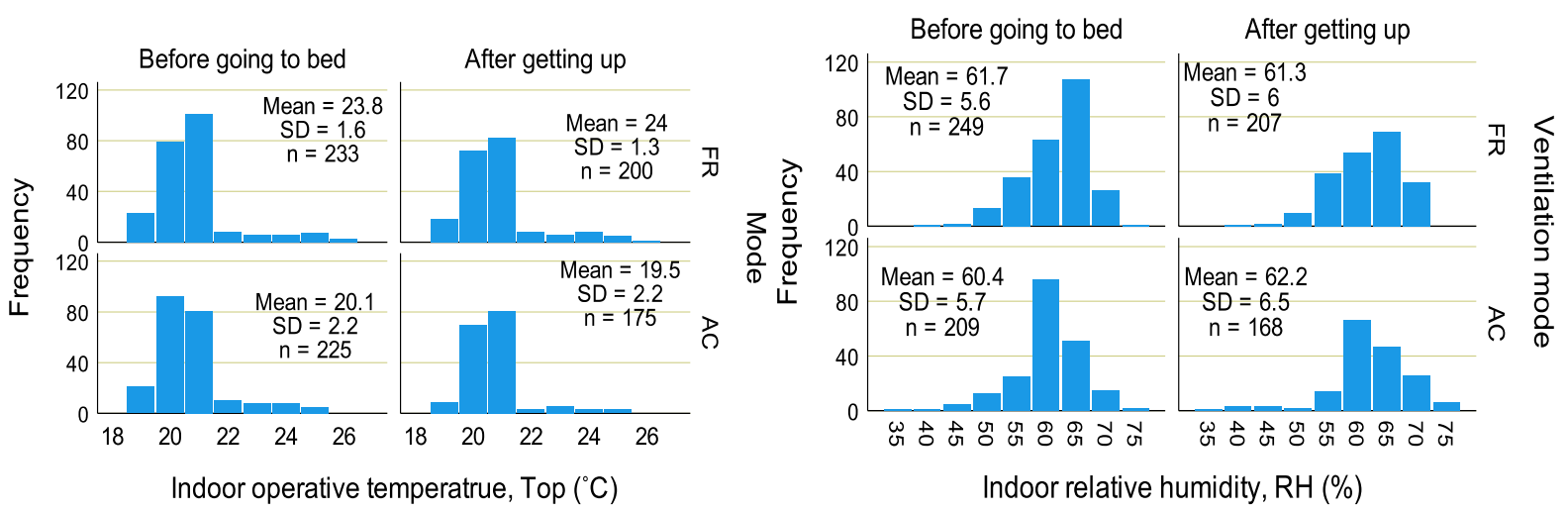

Figure 3. Distribution of indoor operative temperature and relative humidity in FR and AC modes before going to bed and after getting up as noted in the surveys. 

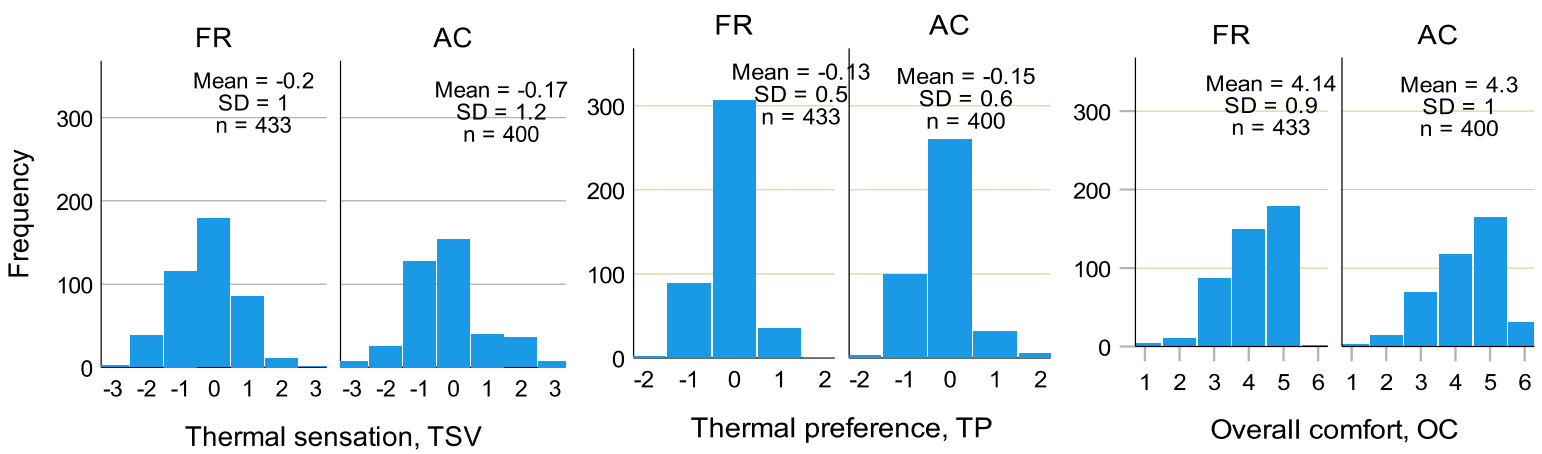

Figure 4. Distribution of thermal sensation, thermal preference and overall comfort votes in FR and AC modes.

Further, in field experiments, most subjects express near-neutral sensations even when the temperature varies in FR mode and vice versa in AC mode. This results in a low coefficient of determination between the temperature and thermal sensation. Literature also points to errors in neutral temperature attributed to the scattering of the thermal sensation and the lack thereof. Therefore, Griffiths method is suggested as a more suitable method for small batches of data. It is estimated using the relationship:

$T_{c}=T_{o p}+(0-T S V) / G$

where $T_{c}$ is the comfort temperature and $G$ is the Griffiths coefficient (Griffiths, 1990). Griffiths method was used to estimate the comfort temperature $\left(T_{c}\right)$ testing initially with three different Griffiths coefficient $(\alpha)$ s: $0.25,0.33$ and 0.50 . Significantly, 0.5 as $\alpha$ resulted in the most reliable prediction of $\mathrm{T}_{\mathrm{C}}$ (with lowest SD value). Therefore, 0.5 was used for $\alpha$ as Humphreys et al. (2016) (p. 251) also suggested. The following mean comfort temperatures and standard deviations were obtained as shown in the parenthesis: in FR mode $24.7{ }^{\circ} \mathrm{C}(\mathrm{SD}=2.3)$ and $23.8{ }^{\circ} \mathrm{C}(\mathrm{SD}=1.9)$ before going to bed and after getting up respectively; and in AC mode $20.8{ }^{\circ} \mathrm{C}(\mathrm{SD}=3)$ and $19.3{ }^{\circ} \mathrm{C}(\mathrm{SD}=$ 3.2) before going to bed and after getting up respectively. These four values are statistically significantly different from one another ( $p<0.05$ ), clearly indicating that the comfort temperature is lower after getting up in both modes. This result is comparable to Hong Kong AC bedrooms in high-rise residences, where Lin and Deng (2006) found the preferred temperature to be below $24{ }^{\circ} \mathrm{C}$.

\subsection{Comparison with International Standards}

To compare, the collected comfort data were superimposed on the Comité Européen de Normalisation (CEN) and The Chartered Institution of Building Services Engineers (CIBSE) Guide standards as shown in Figure 5 a, b. (European Committee for Standardization, 2019; CIBSE, 2015). Observable, in FR mode, most of the data (60\%) was lying within the $\pm 2 \mathrm{~K}$ comfort band of the adaptive relationship, while in AC mode only $18 \%$ was within the respective comfort band. Importantly, $34.9 \%$ and $81 \%$ of data fell below the lower limit of the CEN/CIBSE Guide standards in FR and AC modes respectively. In AC mode, $82.7 \%(n=277)$, and $72.3 \%(n=47)$ cases recorded $T_{c}$ below the CIBSE guide value in these two seasons (Figure 5b). It could mean that subjects were achieving lower winter temperatures by using less heating in winter in AC mode. Having habituated to lower temperatures, the subjects continued maintaining a lower temperature in the spring season also as is evident in Figure 5b. Observable, comfort temperatures were significantly lower in AC mode ( $\mathrm{p}$ $<0.001)$ with large effect size $\left(\eta^{2}>0.14, \mathrm{p}<0.05\right)$ (Figure 5c). A review by Lan et al. (2017) suggested that maintaining lower comfort temperature in winter does not compromise sleep quality, much similar to the result obtained in this study.

\subsection{Evidence of Adaptation}

Qatar has salubrious weather in the winter and spring seasons and as a result, subjects used air-conditioning systems adaptively in residences (mean usage $=48 \%$, $\mathrm{n}=833)$. The proportion using ACs varied significantly with the indoor operative temperature. As this was majorly a winter study, the ACs were used in heating mode and their usage plummeted as the temperature increased as shown in Figure 5d. To estimate the probability of AC use at various indoor temperatures, logistic regression of proportion of AC use ( $\mathrm{p}_{\mathrm{ac}}$ ) with indoor operative temperature was conducted and obtained the following relationship:

$\operatorname{Logit}\left(p_{a c}\right)=-1.248 T_{o p}+27.488$

where $n=833, R^{2}=0.574 ; p<0.001$, and $\mathrm{T}_{\text {op }}$ is the indoor operative temperature $\left({ }^{\circ} \mathrm{C}\right), \mathrm{n}$ is the sample size, $\mathrm{p}$ is the level of significance of the regression coefficient and $\mathrm{R}^{2}$ is the Cox and Snell $\mathrm{R}^{2}$. It can be noted from this relationship that AC usage was $80 \%$ at $20.9{ }^{\circ} \mathrm{C}$. Imagawa and Rijal (2015) noted a similar adaptation in cooling device use in Japanese bedrooms.

\subsection{Sleep Quality}

Figure 6 (a) shows that a significantly higher proportion of people liked the AC systems when about $60 \%$ of the AC systems were in use. This indicated higher proclivity for using ACs at bedtime. Imagawa and Rijal (2015) found slightly lesser (55\%) AC usage when subjects liked the cooling systems. Results also indicated that subjects liking the AC systems had 
significantly higher global PSQI scores. Importantly, subjects in FR mode had significantly higher global PSQI scores than in AC mode, as shown in Figure 6b at all levels of preference for ACs. This figure also shows that residents in Qatar were generally ranked high in PSQI scores, indicating good sleep.

We noticed subjects who accepted the thermal environments had significantly higher self-reported overall sleep quality in both modes as shown in Figure 6c. Tsang, et al. (2021) reported a similar association between overall sleep quality neutral TSV.

Our results also indicated that subjects in AC mode had deeper sleep than in FR mode (Figure 6d). On the other hand, subjects in FR mode had significantly higher comfort temperature than AC mode. However, their comfort temperature at various levels of sensitivity to warmth (SW) did not vary significantly in both modes. It means that the data was not fully explaining the variation in comfort temperature in both modes. On the other hand, results also showed that people sensitive to cold had significantly higher comfort temperature $(\mathrm{p}<0.05)$ than those expressing other sensitivities to warmth as shown in Figure 6e.

A similar association was noted between $\mathrm{T}_{\mathrm{op}}$ and sensitivity to warmth, indicating that other dimensions of the thermal environment such as air movement could have influenced SW.

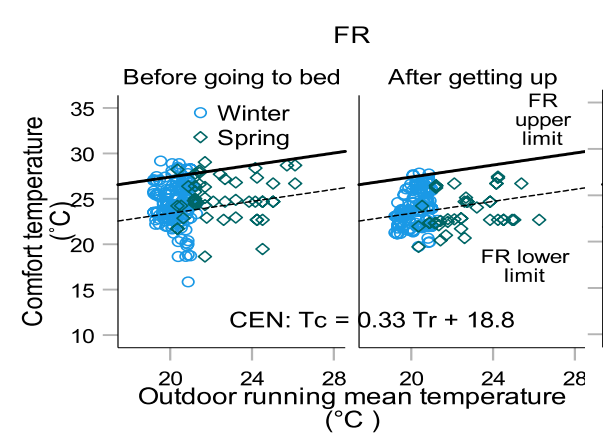

(a)

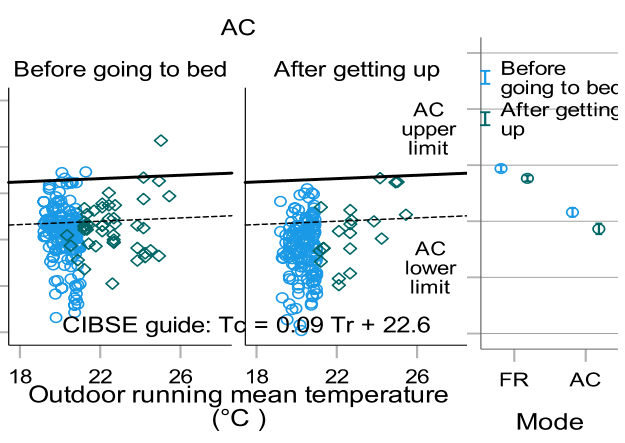

(b)

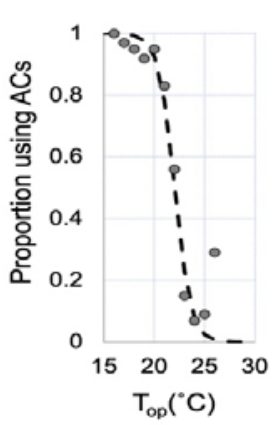

(d)

Figure 5. Comfort data of this research with markers shown for winter and spring seasons for "before going to bed" and "after getting up" cases super-imposed over the European standard for (a) FR and (b) AC modes; (c) significant differences in mean comfort temperature in FR and AC modes in "before going to bed" and "after getting up" cases $(\mathrm{p}<0.05)$; (d) probability of AC use varying with indoor operative temperature, with markers shown for actual proportion or AC use in $1 \mathrm{~K}$ bins. Bins with fewer than ten samples are omitted.

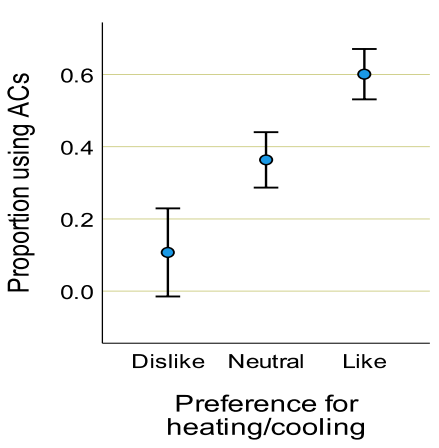

(a)

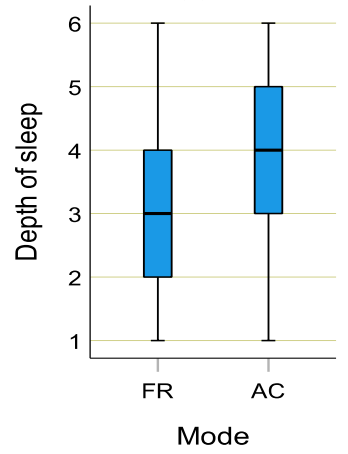

(d)

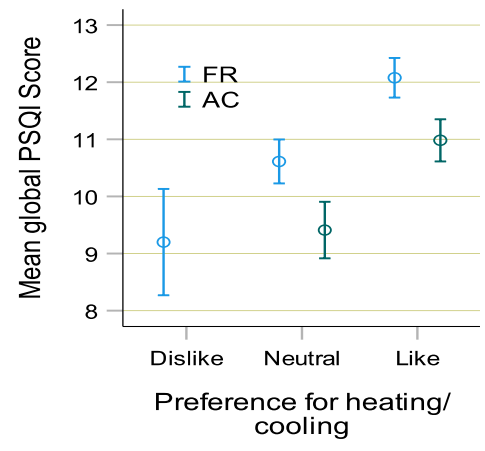

(b)

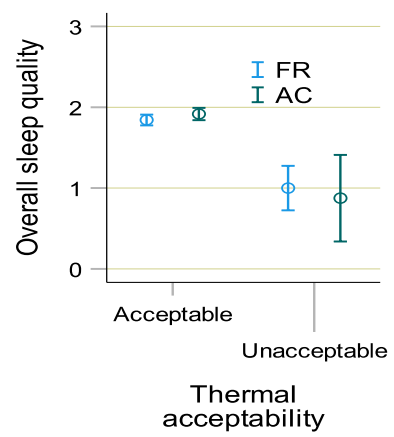

(c)

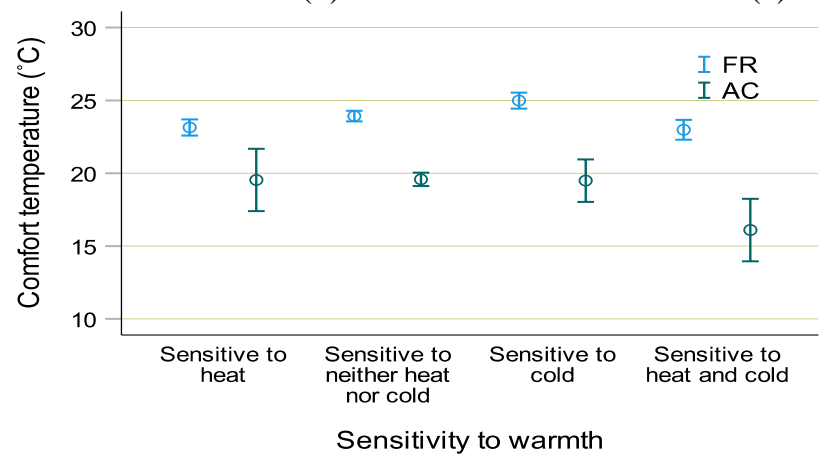

(e)

Figure 6. Association with the three preferences for heating/cooling and (a) mean proportion using ACs, (b) mean global Pittsburgh Sleep Quality Index score; (c) Overall sleep quality varying with thermal acceptability; (d) depth of sleep varying with mode; (f) comfort temperature varying with various levels of sensitivity to warmth. $(\mathrm{p}<0.05)$; $(\mathrm{n}=$ 372). 


\section{CONCLUSION}

A thermal comfort field survey was done in sleep environments in homes in Qatar during the winter and spring seasons of 2020-21. A total of 833 datasets was collected. These contained the thermal comfort data relating to before going to bed and after getting up conditions in six bedrooms. The conclusions are as follows:

1. The subjects expressed cooler sensations and preferred warmer indoors in both FR and AC modes.

2. People are generally comfortable with their sleep environments and the Griffiths comfort temperature $\left(\mathrm{T}_{\mathrm{c}}\right)$ was $24.3{ }^{\circ} \mathrm{C}$ and $20.2^{\circ} \mathrm{C}$ in FR and AC modes respectively. In both modes, $\mathrm{T}_{\mathrm{C}}$ before going to bed was slightly higher ( $\mathrm{p}<$ $0.05)$.

3. Subjects used ACs adaptively in heating mode in winter and tolerated low bedroom temperatures, and as a result, in AC mode $82.7 \%$ of data fell below the lower limit in the CIBSE Guide.

4. The occupants enjoyed quality sleep in Qatar. Overall, self-declared sleep quality significantly improved with thermal acceptability.

5. The depth of sleep was higher in AC mode (mean = 3.86). On the other hand, the mean global Pittsburgh Sleep Quality Index score was high in general, indicating good quality sleep, and significantly so in FR mode (mean =11) compared to the AC mode (mean = 10.4). It increased, as subjects liked their AC systems.

This study suggests that overcooling in spring can be avoided by increasing air movement without compromising sleep quality.

\section{CONFLICT OF INTEREST}

The authors declare no conflict of interest.

\section{FUNDING}

Qatar National Research Fund through the Undergraduate Research Experience Program (Grant numbers: UREP26-033-2-010, UREP26-034-2-011) funded this research. Some instruments used in the survey were funded by the Japan Society for Promotion of Science through a Post-doctoral Fellowship (JSPS/FF1/246/P 11372).

\section{ACKNOWLEDGMENT}

We thank all the survey respondents and both funding agencies. The views expressed in this paper are sole of the authors.

\section{REFERENCES}

Al-ajmi, F. F., Loveday, D. L., Bedwell, K. H. \& Havenith, G., 2008. Thermal insulation and clothing area factors of typical Arabian Gulf clothing ensembles for males and females: Measurements using thermal manikins. Applied Ergonomics, p. 39 (2008) 407-414.

Al-Saffar, A. \& Beeuren, M. V., 2020. The case for energy transitions in major oil- and gas-producing countries. [Online]

Available at: https://www.iea.org/commentaries/

the-case-for-energy-transitions-in-major-oil-and-gasproducing-countries

Anon., 2021. Weather Underground. [Online] Available at: https:/www.wunderground.com/ weather/qa/doha [Accessed 236 2021].

ASHRAE, 2005. ASHRAE Handbook: Fundamentals, SI, Atlanta, GA, USA: American Society of Heating, Refrigerating and Air-Conditioning Engineers, Inc.

ASHRAE, 2020. ANSI/ ASHRAE Standard 55-2020 Thermal environmental conditions for human occupancy, Atlanta: ASHRAE.

Buysse, D. et al., 1989. The Pittsburgh Sleep Quality Index: a new instrument for psychiatric practice and research. J. Psychiatr. Res., 28(2), p. 193-213.

Cheung, T. et al., 2019. Analysis of the accuracy on PMV - PPD model using the ASHRAE Global Thermal Comfort Database II. Building and Environment, Vol.153, pp. 205-217.

CIBSE, 2015. CIBSE Guide A: Environmental Design, London: The Chartered Institution of Building Services Engineers.

Elnaklah, R. et al., 2021. Thermal comfort standards in the Middle East: Current and future challenges. May, p. 107899.

European Committee for Standardization, 2019. EN 16798-1:2019 Energy performance of buildings Ventilation for buildings - Part 1: Indoor environmental input parameters for design and assessment of energy performance of buildings addressing indoor air quality, thermal environment, lighting and acous, Brussels: European Committee for Standardization.

Global Sustainability Assessment System (GSAS), 2015. GSAS Building Typologies: Design Guidelines 2015 - v2.1, Doha: Gulf Organization for Research and Development.

Griffiths, I. D., 1990. Thermal Comfort in Buildings with Passive Solar Features: Field Studies, s.l.: s.n.

Havenith, G. et al., 2015. A Database of Static Clothing Thermal Insulation and Vapor Permeability Values of Non-Western Ensembles for Use in ASHRAE Standard 55, ISO 7730, and ISO 9920. ASHRAE Transactions, 121(1), pp. 197-215.

Humphreys, M. A., 1970. A Simple Theoretical Derivation of Thermal Comfort Conditions. The Journal of the Institute of Heating and Ventilating 
Engineers, 38(8), p. 95-98.

Humphreys, M. A. \& Nicol, J. F., 2002. The validity of ISO-PMV for predicting comfort votes in everyday thermal environments. Energy and Buildings, Vol.34, pp. 667-684.

Humphreys, M., Nicol, F. \& Roaf, S., 2016. Adaptive thermal comfort, Foundations and Analysis. Oxon: Routledge.

IEA, 2018. Key energy statistics 2018. [Online] Available at: https:/www.iea.org/countries/qatar [Accessed 207 2021].

Imagawa, H. \& Rijal, H. B., 2015. Field survey of the thermal comfort, quality of sleep and typical occupant behaviour in the bedrooms of Japanese houses during the hot and humid season. Architectural Science Review, 58(11), pp. 11-23.

Indraganti, M. \& Boussaa, D., 2018. An adaptive relationship of thermal comfort for the Gulf Cooperation Council (GCC) Countries: The case of offices in Qatar. Energy and Buildings, Vol.159 (2018) , p. 201-212.

Indraganti, M., Lee, J. \& Zhang, H. A. E. A., 2015. Thermal adaptation and insulation opportunities provided by different drapes of Indian saris. Architectural Science Review, 58(1), p. 87-92.

ISO, 2005. ISO 7730:2005(E) Ergonomics of the thermal environment - Analytical determination and interpretation of thermal comfort using calculation of the PMV and PPD indices and local thermal comfort criteria, Switzerland: ISO.

Lan, L., Tsuzuki, K., Liu, Y. \& Lian, Z., 2017. Thermal environment and sleep quality: A review. Energy and Buildings, Vol.149, pp. 101-113.

Lan, L., Xia, L., Tang, J. \& Wang, Z., 2019. Elevated airflow can maintain sleep quality and thermal comfort of the elderly in a hot environment. Indoor
Air, Vol.29, p. 1040-1049.

Lin, Z. \& Deng, S., 2006. A questionnaire survey on sleeping thermal environment and bedroom air conditioning in high-rise residences in Hong Kong. Energy and Buildings, Vol.38, pp. 1302-1307.

Lin, Z. \& Deng, S., 2008. A study on the thermal comfort in sleeping environments in the subtropics-Measuring the total insulation values for the bedding systems commonly used in the subtropics. Building and Environment, Vol.43, p. 905-916.

Mitsuzawa, S. \& Tanabe, S.-i., 2001. Effect of air movement on thermal comfort under hot and humid conditions while wearing traditional clothing. London, UK, Proceedings of Moving Thermal Comfort standards into the 21st Century, p. 491500, Windsor Conference.

Morris, N. B. et al., 2021. Electric fan use for cooling during hot weather: a biophysical modelling study. Lancet Planet Health, Vol.5, p. e368-77.

Parkinson, T., de Dear, R. \& Brager, G., 2020. Nudging the adaptive thermal comfort model. Energy and Buildings, Vol.206, p. 109559.

Song, C., Zhao, T., Song, Z. \& Liu, Y., 2020. Effects of phased sleeping thermal environment regulation on human thermal comfort and sleep quality. Building and Environment, Vol.181, p. 107108.

Strøm-Tejsen, P., Zukowska, D., Wargocki, P. \& Wyon, D. P., 2016. The effects of bedroom air quality on sleep and next-day performance. Indoor Air, Vol.26, pp. 679-686.

Tsang, T., Mui, K. \& Wong, L., 2021. Investigation of thermal comfort in sleeping environment and its association with sleep quality. Building and Environment, Vol.187, p. 107406. 